\title{
A Summary of a Cochrane Review: Green and Black Tea for the Primary Prevention of Cardiovascular Disease
}

Nancy Santesso, RD, MLIS, Canada; Eric Manheimer, PhD, United States

Author Affiliations McMaster University, Hamilton, Canada (Ms Santesso) Cochrane CAM Field (Dr Manheimer).

Correspondence Nancy Santesso santesna@mcmaster.ca

Citation Global Adv Health Med. 2014;3(2):66-67. DOI: 10.7453/gahmj.2014.003

Disclosures The authors completed the ICMJE Form for Disclosure of Potential Conflicts of Interest and disclosed receipt by their institutions of grants from the National Institutes of Health National Center for Complementary and Alternative Medicine.

Acknowledgment This article was prepared on behalf of the Cochrane Complementary and Alternative Medicine Field with funding from the US National Center for Complementary and Alternative Medicine (NCCAM) of the US National Institutes of Health (grant number R24 AT001293).

\section{INTRODUCTION}

Review authors in the Cochrane Collaboration conducted a review of the effects of green and black tea to prevent cardiovascular disease (CVD), such as heart attack and stroke. After searching for all relevant studies, they found II studies in 82I people who were healthy or at high risk of CVD. The findings of the review are summarised below.

\section{TEA AND CARDIOVASCULAR DISEASE}

CVD refers to many diseases that affect the heart and blood vessels. CVD includes cerebrovascular disease (such as stroke); peripheral arterial disease, in which arteries become blocked with plaque; and coronary heart disease, which can lead to a heart attack. Because CVD causes almost 30\% of deaths around the world, there is research into ways to prevent and lower the risk of CVD. Preventing CVD can involve ways to lower blood pressure, lower triglyceride levels, lower total cholesterol levels, and lower the "bad" cholesterol (LDL) but raise the "good" cholesterol (HDL). Researchers have been testing whether certain foods or drinks could help prevent CVD.

Tea has been used as medicine in many countries, and different types of tea have become popular. The two most popular types of tea are black and green.
These teas are produced from the same leaves but using different methods. This means they contain different vitamins and minerals and different amounts of flavanols (a type of flavanoid) and caffeine. The question is, could drinking tea or taking tea extract prevent CVD?

\section{WHAT DOES THE RESEARCH SAY?}

There were I I studies that tested the effects of tea on the risk of CVD after 3 to 6 months. People who were healthy or who already had a high risk of CVD were in the studies. Green tea and black tea were tested sometimes as tea and sometimes as pills that contained tea extract.

The evidence from the research was moderate quality or low quality. "High quality" means something will happen, moderate quality means it probably will happen, and "low quality" means it may happen. "Very low quality" evidence means it is uncertain.

The studies show that after 3 to 6 months, green or black tea

- may lower diastolic and systolic pressure slightly

- probably lowers bad cholesterol (LDL)

- probably has little or no effect on good cholesterol (HDL)

- may lower total cholesterol

- probably has little to no side effects

\begin{tabular}{|c|c|c|c|c|}
\hline What Was Measured & Without Tea & With Tea & $\begin{array}{l}\text { Quality of the } \\
\text { Evidence }^{a}\end{array}$ & What Happens After 3-6 mo \\
\hline $\begin{array}{l}\text { Diastolic blood pressure } \\
\text { (4 studies, } 290 \text { people) }\end{array}$ & $2 \mathrm{~mm} / \mathrm{Hg}$ lower & $\begin{array}{l}\text { Lower by } 2.8 \mathrm{~mm} / \mathrm{Hg} \text { more } \\
\text { (from } 1.9 \text { to } 3.8 \text { more) }^{\mathrm{b}}\end{array}$ & $\begin{array}{l}\oplus \oplus \ominus \ominus \\
\text { low }\end{array}$ & $\begin{array}{l}\text { Tea may lower diastolic blood } \\
\text { pressure slightly }\end{array}$ \\
\hline $\begin{array}{l}\text { Systolic blood pressure } \\
\text { (4 studies, } 290 \text { people) }\end{array}$ & $1 \mathrm{~mm} / \mathrm{Hg}$ lower & $\begin{array}{l}\text { Lower by } 2.3 \mathrm{~mm} / \mathrm{Hg} \text { more } \\
\text { (from } 1.1 \text { to } 3.4 \text { more) }^{\mathrm{b}}\end{array}$ & $\begin{array}{l}\oplus \oplus \Theta \Theta \\
\text { low }\end{array}$ & $\begin{array}{l}\text { Tea may lower systolic blood } \\
\text { pressure slightly }\end{array}$ \\
\hline $\begin{array}{l}\text { Bad cholesterol (LDL) } \\
\text { (8 studies, } 474 \text { people) }\end{array}$ & $\begin{array}{l}\text { From } 0.2 \text { lower to } \\
0.3 \mathrm{mmol} / \mathrm{L} \text { higher }\end{array}$ & 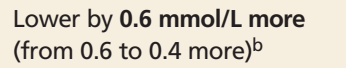 & $\begin{array}{l}\oplus \oplus \oplus \ominus \\
\text { moderate }\end{array}$ & $\begin{array}{l}\text { Tea probably lowers "bad" } \\
\text { cholesterol (LDL) }\end{array}$ \\
\hline $\begin{array}{l}\text { Good cholesterol (HDL) } \\
\text { (8 studies, } 473 \text { people) }\end{array}$ & $\begin{array}{l}\text { From } 0.04 \text { lower to } \\
0.2 \mathrm{mmol} / \mathrm{L} \text { higher }\end{array}$ & $\begin{array}{l}\text { Change of } 0 \mathrm{mmol} / \mathrm{L} \\
\text { (from } 0.04 \text { more to } 0.04 \text { less) }^{\mathrm{b}}\end{array}$ & $\begin{array}{l}\oplus \oplus \oplus \ominus \\
\text { moderate }\end{array}$ & $\begin{array}{l}\text { Tea probably has little or no effect } \\
\text { on "good" cholesterol (HDL) }\end{array}$ \\
\hline $\begin{array}{l}\text { Total cholesterol } \\
\text { (7 studies, } 446 \text { people) }\end{array}$ & - & Lower in 4 out of 6 studies & $\begin{array}{l}\oplus \oplus \ominus \ominus \\
\text { low }\end{array}$ & $\begin{array}{l}\text { Tea may lower total } \\
\text { cholesterol }\end{array}$ \\
\hline $\begin{array}{l}\text { Side effects } \\
\text { (4 studies, } 290 \text { people) }\end{array}$ & - & - & $\begin{array}{l}\oplus \oplus \oplus \ominus \\
\text { moderate }\end{array}$ & $\begin{array}{l}\text { Tea probably has little or no } \\
\text { side effects }\end{array}$ \\
\hline \multicolumn{5}{|c|}{ Death, heart attack, or stroke Not measured in these studies } \\
\hline \multicolumn{5}{|c|}{$\begin{array}{l}\text { a Details about the quality of the evidence: } \\
\text { Evidence was moderate quality due to the risk of bias in studies because there may not have been random sequence generation or allocation concealment. } \\
\text { Evidence was low quality due to risk of bias and the imprecise results from the small number of participants in the studies or because the studies could not be } \\
\text { combined statistically. }\end{array}$} \\
\hline
\end{tabular}


None of the studies measured whether having tea would lead to fewer deaths, heart attacks, or strokes. It is also not clear what is the best amount of tea or whether drinking tea or taking tea extract in pill form is better.

\section{WHERE DOES THIS INFORMATION COME FROM?}

This summary is based on a Cochrane systematic review: Hartley L, Flowers N, Holmes J, Clarke A, Stranges S, Hooper L, Rees K. Green and black tea for the primary prevention of cardiovascular disease. Cochrane Database Syst Rev. 2013 Jun I8;6:CDoog934.

The Cochrane Collaboration is an independent global network of people who publish Cochrane systematic reviews. Many of the people are volunteers who write reviews by pulling together scientific studies to answer healthcare questions. These reviews may answer questions about whether, for example, certain vitamins work in diabetes. The Cochrane Complementary and Alternative Medicine Field promotes Cochrane systematic reviews which cover complementary and alternative medicine in many conditions and diseases. For more information, please visit http://www.compmed.umm.edu/cochrane/.

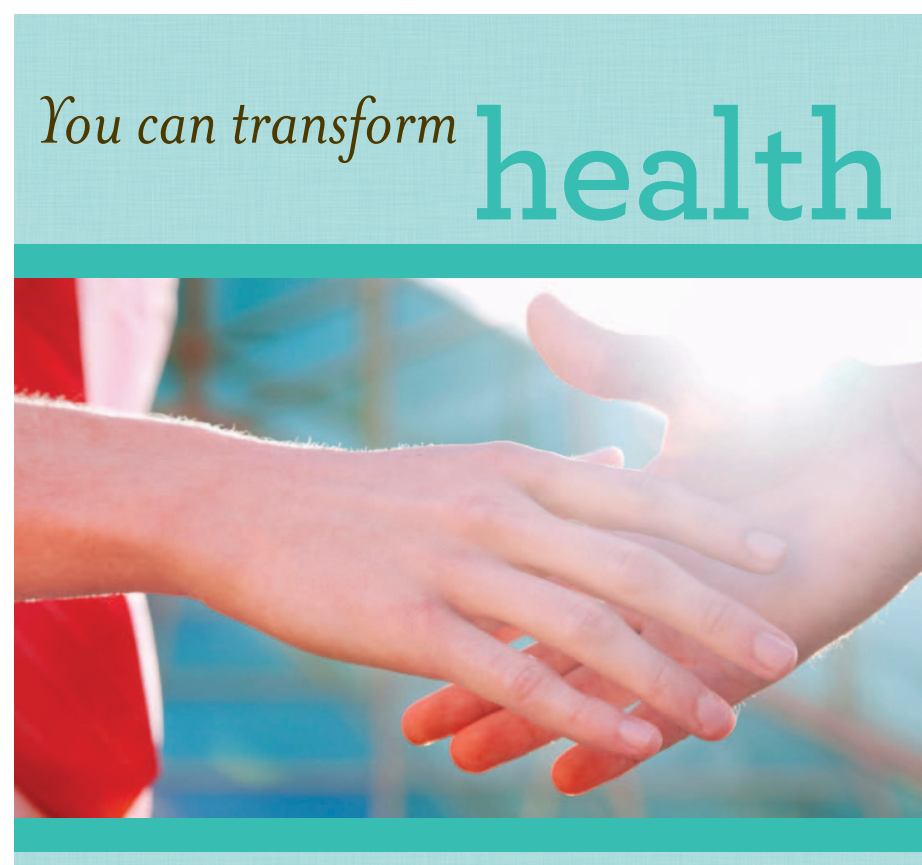

BE A HEALTH COACH. BE PART OF THE TRANSFORMATION OF HEALTH CARE.

Since 2005, the University of Minnesota's Center for Spirituality \& Healing has offered a formal track in health coaching under our graduate-level, Post-Baccalaureate Certificate in Integrative Therapies and Healing Practices. Offered in a blended format, students only have to be on campus for 2, 4-day weekends a semester. The rest is done on the computer and phone. Students join us from all over the United States.

Health coaching is a new and evolving profession designed to meet the needs of people actively seeking to improve their health and wellbeing in the midst of complex and often confusing healthcare options.

Individuals seeking prevention as well as those dealing with complex illness issues can benefit from a personalized care plan that a Health Coach can help them develop. Such services are offered in a variety of settings including hospitals, clinics, businesses, health clubs, and private practices.

Are you ready to be part of this new frontier in the healthcare experience? Submit your application today.

To learn more or apply, please contact Pamela at cherroo6@umn.edu or visit z.umn.edu/hc 